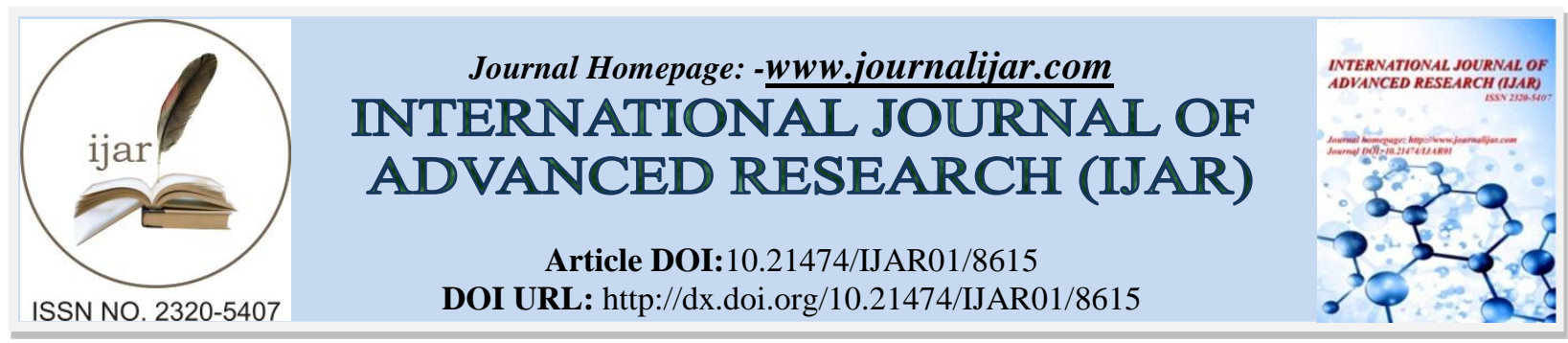

RESEARCH ARTICLE

\title{
STUDY OF CAREER MATURITY IN RELATION TO WELL BEING OF SENIOR SECONDARY SCHOOL STUDENTS.
}

\author{
Santosh kumari. \\ Assit. Proff., j.d. College of education, sri muktsar sahib.
}

\section{Manuscript Info}

Manuscript History

Received: 05 January 2018

Final Accepted: 07 February 2019

Published: March 2019

\begin{abstract}
The youth of the country find it difficult to choose their career. The construct of career maturity consists of a readiness, attitude and competency to cope effectively with the career development tasks career maturity assumes a great importance in the life of students for their proper future placement. It is the pre requisite ability to make a wise choice towards particular occupation and represent development along a continuum. Difficulty in making a career choice is closely related to career maturity and is one of the primary challenges facing students. The understanding of vocational world is vital for students as it enables them to review their career decisions in the light of their potentialities. For proper guidance in the section of courses of studies as well as in occupation, career maturity and well being plays an important role.
\end{abstract}

Copy Right, IJAR, 2019,. All rights reserved.

\section{Introduction:-}

The aim of the education are multiply, but the primary aim of education is to make an individual understand one's self and be able to decide upon one vocation or the other successful career development often involves setting realistic, deliberate goals, simultaneously for cohesiveness between employees and employer. Understanding how occupation preferences ware identified based on knowledge of self and work can be instrumental in positive career development and satisfying placement. The choice is fraught with difficult and affect every aspect of an individual's existence. Career affects lifestyle, prestige, and living conditions. Although it would be comforting to assume that the choice of a career is a smooth process with a successful outcome that is not always the case. Career selection begins in secondary school students at a time when young adults are also trying to forge their own identities and mature into students. The ability to make a career decision is also affected by a loick of academic preparation and limited access to career experiences, and career maturity.

Career mature individual have the ability to identify specific occupational preferences and to implement activities in order to achieve goals. Changes in the economy, such as recessions, downsizing an increased exportation of jobs, and layoffs, requires that today's youth are preparing for the new realities of $21^{\text {st }}$ century labor market by building strong foundations for career decision making across the lifespan. For even that most prepared, motivated young person, developing and maturity necessary to make informed career decisions in this complex and constantly demanding world of work is changing. It is clear that in our modern world, making a career choice is not a single decision made at one point in time, but a process involving many decision, great and small, that combine to set one on an individualized trajectory of career development. The process of vocational decision- making begins from an early age; it is evident in the young child who has a ready answer to the question, what do you want to be when you 
grew up? And continues in some developmentally appropriate from throughout the life span. In this period senior secondary school students begin to make significant decision about their future education and career paths, as well as how to identify their aspirations and how set their educational and career goals. The many career decisions that a person makes, beginning with one's first career fantasy and continuing through students and their age, involve a complex synthesis of personal, social and environmental components. There, it is imperative that these students develop the efficacy, skills, and readiness to make adaptive career decisions and set viable career choice goals. An individual either male or female has to play several roles in his/her life. An emotional immature and dissatisfied individual cant' reaches to the expectations of the society and can't carry his burdens. Career maturity and career decision making well being are important components for understanding for senior secondary school students career behaviors has will has assessing other progress towards achieving variables career choice goals.

Career maturity is the extent to which an individual able to master certain career developmental tasks that is applicable to his/her life stage. It is extremely important to identify an individual's state of career maturity in order to give appropriate career guidance. The construct of career maturity consists of a readiness, attitude and competency to cope effectively with the career development tasks. The assumption can be made that a career mature person is more capable of making an appropriate and realistic career choice and decision.

Well being concerns with how and why people experience their lives in positive ways including both cognitive judgments and affective reactions. As such it covers studies that have used such diverse terms as happiness, satisfaction, morale and positive self concept. Wellbeing can also be stated as the capacity to establish positive aspect of life, general satisfaction, sense of achievement and to be fully satisfied.

In this period senior secondary school students begin to make significant decisions about their future educational and career paths, as well as how to identify their aspirations and how to set their educational and career goals. Therefore, it is imperative that these youth develop the well being.

\section{Statement of the problem}

Study of career maturity in relation to well being of the senior secondary school students.

\section{Objectives of the study}

The study was carried out with the following objectives:

1. To study the difference of students towards career in relation to their well being.

2. To study the difference in career maturity of students in relation to their well being.

\section{Hypotheses of the study}

1. There is no significant difference of students towards career in relation to their well being.

2. There is no significant difference in career maturity of students in relation to their well being.

\section{Sample of the study}

The sample of the present study comprises 200 students selected from senior secondary schools of Muktsar city. The sample was balanced between 100 boys and 100 girls, of homogeneous groups.

\section{Tools used}

In the present study the investigator used the following standardized tools to collect the data.

1. Career maturity inventory developed by John O’ Crities (1989).

2. Well being

\section{Statistical Techniques used}

1. $\mathrm{t}$-ratio was employed to see the gender differences and stream differences within the groups on the variables.

2. Pearson's coefficient $\mathrm{R}$ of correlation was computed for the purpose of finding relationship among career maturity scale and well being scale.

\section{Analysis and interpretation of the data}

Relationship between career maturity and well being was calculated with the help of pearson's correlation method. Results are presented in the following tables. 


\begin{tabular}{|l|l|l|}
\hline Variable & T-ratio & R ratio \\
\hline Career maturity & 1.00 & $0.158^{*}$ \\
\hline Well being & & 1.00 \\
\hline
\end{tabular}

Table showing values of coefficient correlation between career maturity and well being. Thus career maturity and well being of secondary school students related positively to each other. In other words as the career maturity increases, so is the case with their well being.

\section{Conclusions:-}

On the basis of analysis of the data, the following conclusion was drawn:

1. There is no significant difference in attitude of the students towards career. It means that they have equal attitude of boys and girls toward career.

2. There is no significant difference in career maturity of students in relation to their well being. Thus we can say that they have equal career maturity in relation to their well being.

\section{Educational implications}

1. The finding of the study is likely to prove of immense important to educational thinkers, teachers, psychologist, parents and others who are concerned with the sphere of education.

2. This study will help to understand the level of career maturity and well being of the students.

3. This study will help the teacher to know about the vocational problems and vocational interest of the students.

4. If career planning were done in efficient manner, students would at the very least be following a career plan of informed decision making, rather than one of happenstance.

\section{References:-}

1. Adam, C., creasy. (20060. The effect of gender, year in school, plans to play professionally and idently on students athietes, adoption of goal orientation in academics. Faculty of graduate schools of the university. Texas at Austin in repositories. Lib. Texas. Edu/Bitstream/handle/2152/77813.pdf?

2. Arbona,C. (1990). Career counseling research and Hispanics: a review of the literature. The counseling psychologist, 18. 300-323.

3. Johnson, R.b. \& onwuegbuzie, A.J.(2004). Mixed method research: a research paradigm whose time has come. Educational researcher, 33(7), 14-26.

4. Lindley, L.D. (20050. Perceived barriers to career development in the context of social cognitive career theory. Journal of career assessment, 13 930, 271-287.

5. Mangal,S.k. (2010). Advanced educational psychology. New delhi. PHI learning private limited.

6. Singh \& Gupta. (2001). A study of well being among senior secondary school teachers of Punjab in realtion to coping strategies and school organizational climate. Ph.D. thesis, H.P. University, Shimla.

7. Smithy, H.C. (1955). Psychology of Industrial Behaviour, New York; Mc Graw hill Book co. 